\title{
New records of bats (Mammalia: Chiroptera) and karyotypes from Guinean Mount Nimba (West Africa)
}

\author{
C. DENYS ${ }^{1 \star}$, B. KADJO $^{2}$, A. D. MISSOUP ${ }^{3}$, A. $_{\text {MONADJEM }}^{4,5}, \&$ V. AN I S K I N E \\ ${ }^{1}$ UMR7205CNRS, Origin, structure and Evolution of Biodiversity, Department Systematics E Evolution, MNHN, Paris, \\ France, \\ ${ }^{2}$ University of Cocody-Abidjan, UFR Biosciences, Abidjan, Côte d'Ivoire, \\ ${ }^{3}$ University of Douala, Sciences Faculty, Department of Animal Biology Organisms, Douala, Cameroun, \\ ${ }^{4}$ Department of Biological Sciences, University of Swaziland, Kwaluseni, Swaziland, \\ ${ }^{5}$ Mammal Research Institute, Department of Zoology E Entomology, University of Pretoria, Pretoria, South Africa, and \\ ${ }^{6}$ Severtsov Institute of Ecology and Evolution, Moscow, Russia
}

${ }^{*}$ Correspondence: C. Denys, UMR7205CNRS, Origin, structure and Evolution of Biodiversity, Department Systematics \& Evolution, MNHN, 55 rue Buffon, 75231 Paris Cedex 05, France.Email: denys@mnhn.fr

\begin{abstract}
New bats were recorded from various habitats on the Guinean side of Mount Nimba during two surveys in 2008 and coupled with a cytotaxonomic survey. A total of 152 specimens comprising 15 species in 12 genera from five families were collected, of which 13 individuals were karyotyped. The most numerous species was Rhinolophus guineensis followed by four fruit bats (Epomops buettikoferi, Lissonycteris angolensis, Roussettus aegyptiacus, Nanonycteris veldkampii). We confirm the presence of Hipposideros lamottei in the mine adits at $1500 \mathrm{~m}$ as well as the exceptional diversity of this habitat. First standard karyotypes are provided for Epomops buettikoferi and Nanonycteris intermedia. We also document for the first time karyotypes for West African populations of Mops thersites, Lissonycteris angolensis and Roussettus aegyptiacus, and cytogenetical comparisons with the existing literature are provided. We add five new species to the list of Guinean Nimba and two to the whole Nimba list (including Liberian side), which now stands at 42 species. This confirms the importance of Mount Nimba as a hotspot of diversity and the necessity to protect it.
\end{abstract}

Keywords: Chiroptera, Mount Nimba, West Africa, cytogenetics, diversity

\section{Introduction}

Bats are the second most abundant order of mammals, representing $25 \%$ of its diversity in 1116 species (Wilson \& Reeder 2005). This figure is steadily rising as many taxonomic studies, based on genetics, morphology and acoustic characteristics, have recently highlighted the existence of significant cryptic diversity in this taxon (Kingston et al. 2001; Vallo et al. 2008; Taylor et al. 2012; Monadjem et al. 2013).

The forests of tropical Africa are considered as hotspots of biodiversity (Myers et al. 2000; Olson et al. 2001). By acting as refugia during cold periods, they are considered as promoters of biodiversity in west central Africa (Nicolas et al. 2011; Missoup et al. 2012). Some studies demonstrated that diversity may also arise at the ecotone between forest and savanna (T.B. Smith et al. 2005; Fahr \& Kalko 2011). Montane forests also play a role in shaping tropical African biodiversity by constituting terrestrial islands (White 1981; Kingdon 1990; Taylor et al. 2012), isolated by altitude and changes in habitat.

In tropical west and central Africa, different montane blocks are scattered in the lowland Guineo-Congolian forest but their mammalian fauna has attracted less attention than those of the Eastern Arc (Newmark 2002; Stanley \& Goodman 2011) or Ethiopian highlands (Yalden \& Largen 1992; Kasso et al. 2010). Prominent among the West African highlands is Mount Nimba, which straddles the borders of Guinea, Ivory Coast and Liberia. This mountain is considered as a prime hotspot for African 
mammals (Olson et al. 2001; Mittermeier et al. 2005) and it was designated a UNESCO Biosphere Reserve in 1980. Mount Nimba harbours an exceptionally rich biological diversity, with numerous endemic taxa including the bat Hipposideros lamottei Brosset, 1984. Despite a rather low altitude [highest peak at $1768 \mathrm{~m}$ above sea level (asl)], the exceptional geology of the site has allowed the development of edaphic vegetation assemblages that are unique (Lamotte \& Roy 1962). Extensive savannas occur at higher elevations, forming an island of montane grasslands interdigitated among blocks of Upper Guinean Forest.

Bat diversity in Mount Nimba has been documented in a number of previous studies, which have mostly focused on the Liberian side of the mountain (Coe 1975; Verschuren 1976; Hill 1982; Wolton et al. 1982), with fewer studies on the Guinean side (Lamotte 1942; Aellen 1963; Brosset 1985). In a review of the bats recorded from Guinean Mount Nimba, Brosset (2003) confirmed the occurrence of 39 species and suggested that this may be one of the most diverse bat communities on the African continent. Brosset (2003) also noted the exceptionally high number of Pteropodidae present at this site as well as the high diversity of bats from montane forest above $800 \mathrm{~m}$ asl. Furthermore, Monadjem et al. (2013) also reported a highly diverse assemblage of 10 species of pipistrelloid bats from the Liberian side of Mount Nimba.

This paper reports on a bat survey conducted as part of a global inventory on the small mammal fauna of Guinean Mount Nimba. The objectives are: (1) to document new records of bats from Guinean Mount Nimba and to provide a recent update of the bat diversity in the Nimba region, and (2) to report karyotypes for some of these species.

\section{Study area}

We captured bats in four different localities in Guinean Mount Nimba (Table I). The first locality was Seringbara (550-620 m asl), situated on the southwestern flank of the highest peak, "Richard Molard", $5 \mathrm{~km}$ east of Bossou station and covered by dense primary and secondary forest. The second site was Gbie (540-620 m asl). It consisted of enclosed savanna of anthropic origin within secondary forest on the northeastern flank of the mountain, about $6 \mathrm{~km}$ from Nzo village. The third locality was situated in the Societe des Mines de Fer de Guinea (SMFG) mining concession (1498 $\mathrm{m}$ asl). It is constituted of old mine adits in high altitude grasslands at "Pierre Richaud". Finally, bats were also captured adjacent to the SMFG mining camp (City I and II), between the Gouan and Zougue rivers at an intermediate altitude (800-1200 $\mathrm{m}$ asl).

\section{Data collection and analysis}

During the dry (February-March) and the wet (September-October) seasons of the year 2008, six $12-\mathrm{m}$ mist nets with five shelves, $16-\mathrm{mm}$ mesh and 110-denier thickness were set at the different sites. At each site, nets were set across potential flight paths of bats such as rivers and streams, swampy areas, paths through forest or at the ecotone between savanna and forest. They were also placed at the entrance of two mine adits for one night. The nets were opened for several hours from dusk till after midnight (generally 7:00 pm to 01:00 am). In the field, the following morphological measurements were taken from each captured bat: length of forearm (FA), length of the tibia (TIB), and length of ear (E).

Skulls were either prepared in the field (by Fode Kourouma) or at the Service of Osteological and Taxidermy Preparation (SPOT) in the Muséum d'Histoire Naturelle (MNHN), Paris, and measured using a pair of Mitutuyo calipers with a precision of $0.01 \mathrm{~mm}$.

Thirteen specimens were kept for standard karyotypic analyses, which were conducted directly in the field by one of us (VA) (SER175, 179, 180,

Table I. Trapping effort at the various locations during the dry (February-March) and wet (September-October) seasons at Guinean Mount Nimba during 2008. See the text for a more detailed description of the habitat at each location.

\begin{tabular}{|c|c|c|c|c|c|}
\hline \multirow{2}{*}{ Location } & \multirow{2}{*}{ Habitat } & \multirow[t]{2}{*}{ Altitude (m) } & \multicolumn{2}{|c|}{ Trap effort (net nights) } & \multirow[t]{2}{*}{ Total } \\
\hline & & & Dry season & Wet season & \\
\hline Gbie & Savanna/forest ecotone & $540-620$ & 6 & 10 & 16 \\
\hline Gouan camp & Disturbed savanna/forest & $800-1200$ & - & 14 & 14 \\
\hline Pierre Richaud & Montane grassland & 1498 & $2^{*}$ & - & 2 \\
\hline Seringbara & Lowland forest & $550-600$ & 30 & 17 & 47 \\
\hline Total & & & 38 & 41 & 79 \\
\hline
\end{tabular}

*These nets were set up at the entrance of mine adits and therefore only captured bats that were roosting in the adit. 
181, 183, 189, 190; GBIE196, 197, 223, 245, 246, 255) and three specimens sequenced (NIMI123, NIM1108, NIM1110, cytochrome B; Monadjem et al. submitted). Metaphase chromosome preparations were obtained by the standard colchicine method following the protocol of M.R. Lee and Elder (1980).

All specimens have been deposited in the Mammal section of the MNHN collections. For identifications we compared our new specimens to voucher collections based on previous surveys (e.g. Brosset 1985, 2003) and housed in the MNHN.

\section{Results}

A total of 152 bats were netted during this study, comprising five families, 12 genera and 15 species. The single largest contribution by family was the Pteropodidae (69.7\% of all captures) with an average capture rate of success of 0.37 bats per $12 \mathrm{~m}$ mist net hour $(\mathrm{b} / \mathrm{mh})$, vs $0.15(\mathrm{~b} / \mathrm{mh})$ for insectivorous bats. The greatest capture of individual species was Rhinolophus guineensis (21.1\% of all captures), Nanonycteris veldkampii (19.1\%), Epomops buettikoferi (11.2\%) and Rousettus aegyptiacus (10.5\%). These proportions were similar between the wet and dry seasons except for $R$. guineensis, which was predominantly captured during the dry season (Table II). External measurements, standard karyotype (when available) and localities from which each species was collected in Guinean Mount Nimba are presented in Table III.

\section{Family Pteropodidae Gray, 1821}

Two males of Hypsignathus monstrosus Allen, 1861 were netted from Nimba: one during the dry season in the lowland forest of Seringbara and the other in the wet season in Gouan Camp. This is the largest species of bat recorded for this region.

Another Pteropodidae, Epomops buettikoferi (Matschie, 1899) was represented by 18 specimens; six (five males and one female) from Seringbara and 12 (four males and eight females) from Gbie and Gouan. It was present in a variety of habitats from forest to the savanna-forest ecotone. Four specimens were karyotyped (SER180, 181, 183, 190), all from lowland forest of Seringbara. The karyotype consisted of 34 autosomes and two (XX) or one (X0) gonosomes in females $(2 \mathrm{n}=36)$ and males $(2 \mathrm{n}=35)$, respectively. The autosomal set comprised 17 pairs of bi-armed chromosomes decreasing in size, thus resulting in $\mathrm{NFa}$ (Fundamental Number of autosomes) $=68$ (Figure 1). The $\mathrm{X}$ chromosome was submetacentric of medium-sized.

A total of 16 specimens belonging to Lissonycteris angolensis smithii Thomas, 1908 was captured during this study; six (two males and four females) from lowland forest at Seringbara and 10 (five males and five females) from mine adits at Pierre Richaud (Table III). The chromosome set of the studied female from Seringbara consisted of 16 pairs of meta/submetacentric decreasing in size, one pair of very small acrocentric and two mediumsized submetacentric $\mathrm{X}$ chromosomes, resulting in $2 \mathrm{n}=36$ and $\mathrm{NFa}=66$ (Figure 2).

Nine representatives of Megaloglossus woermanni Pagenstecher, 1855 (two males and seven females) were collected, of which eight were in the dry season and one in the wet season, all from the lowland forest at Seringbara (Table III).

We captured nine specimens (eight females and one male) of Micropteropus pusillus (Peters, 1868), one in savanna at Gbie and the rest at the Gouan mining camp (Table III).

A total of nine specimens (four females and five males) of Myonycteris torquata (Dobson, 1878) were captured, three from forest habitat at Seringbara in the dry season and the rest during the wet season at Gouan mining camp (Table III).

We netted 29 specimens (16 males and 13 females) belonging to Nanonycteris veldkampii (Jentink, 1888) during both wet and dry seasons, all in forest habitat at Seringbara (Table III).

One of the most abundant species in our nets was Rousettus aegyptiacus unicolor (E. Geoffroy, 1810), with 17 specimens captured, of which three individuals (two females and one male) were from savanna at Gbie and 14 (nine males and five females) from forest at Seringbara (Table III). Four specimens (three females, GBI197, GBI245 and GBI246, and one male, GBI255) from our study showed karyotype $2 \mathrm{n}=36, \mathrm{NFa}=66$ (Figure 3). Despite sharing similar diploid and fundamental numbers, and $\mathrm{X}$ chromosomes, with Lissonycteris angolensis, the karyotype of these two species showed some differences. The autosomes of $R$. aegyptiacus consist of 12 metacentric pairs (L. angolensis has 11 pairs, two submetacentric pairs ( $L$. angolensis has three pairs), two subtelocentric pairs and one small acrocentric pair. The $\mathrm{Y}$ chromosome is the smallest chromosome in the complement.

\section{Family Rhinolophidae Gray, 1825}

A total of 40 specimens (11 females and 29 males) of Rhinolophus guineensis Eisentraut, 1969 were 
Table II. Bat diversity, trap effort, number of individuals, relative abundance and abundance in the different habitat types sampled at Guinea forest region. CR, critically endangered; VU, vulnerable; LC, least concern; DD, data deficient. b/mh: bat per $12 \mathrm{~m}$ mist net hour; DST, dry season trapping; WST, wet season trapping; TT, total trapping.

Species

Dry season DST $(\mathrm{b} / \mathrm{mh})$ Wet season WST $(\mathrm{b} / \mathrm{mh})$ Total TT $(\mathrm{b} / \mathrm{mh})$

Relative

RED LIST abundance (\%)

\begin{tabular}{|c|c|c|c|c|c|c|c|c|}
\hline \multirow{2}{*}{\multicolumn{2}{|c|}{$\begin{array}{l}\text { Trapping effort } \\
\text { Pteropodidae }\end{array}$}} & \multicolumn{2}{|l|}{0.15} & \multicolumn{2}{|l|}{0.12} & \multicolumn{3}{|l|}{0.27} \\
\hline & & & & & & & & \\
\hline $\begin{array}{r}\text { Epomops buettikoferi } \\
\text { (Mastchie, 1899) }\end{array}$ & 7 & 0.19 & 10 & 0.28 & 17 & 0.47 & 11.18 & LC \\
\hline $\begin{array}{l}\text { Hypsignathus monstrosus } \\
\text { H. Allen, } 1861\end{array}$ & 1 & 0.03 & 1 & 0.03 & 2 & 0.06 & 1.32 & LC \\
\hline $\begin{array}{l}\text { Lissonycteris angolensis } \\
\quad \text { smithii (Thomas, 1908) }\end{array}$ & 11 & 0.31 & 4 & 0.11 & 15 & 0.42 & 9.87 & LC \\
\hline $\begin{array}{l}\text { Megaloglossus woermanni } \\
\text { Pagenstecher, } 1885\end{array}$ & 8 & 0.22 & 1 & 0.03 & 9 & 0.25 & 5.92 & LC \\
\hline $\begin{array}{l}\text { Micropteropus pusillus } \\
\quad \text { (Peters, 1867) }\end{array}$ & 1 & 0.03 & 8 & 0.22 & 9 & 0.25 & 5.92 & LC \\
\hline $\begin{array}{l}\text { Myonycteris torquata } \\
\text { (Dobson, 1878) }\end{array}$ & 3 & 0.08 & 6 & 0.17 & 9 & 0.25 & 5.92 & LC \\
\hline $\begin{array}{l}\text { Nanonycteris veldkampii } \\
\quad \text { (Jentink, 1888) }\end{array}$ & 11 & 0.31 & 18 & 0.50 & 29 & 0.81 & 19.08 & LC \\
\hline $\begin{array}{l}\text { Rousettus aegyptiacus } \\
\text { unicolor (Gray, 1870) }\end{array}$ & 10 & 0.28 & 6 & 0.17 & 16 & 0.44 & 10.53 & LC \\
\hline $\begin{array}{l}\text { TOTAL } \\
\text { MEGACHIROPTERA }\end{array}$ & & & & & 106 & 0.37 & 69.74 & \\
\hline \multicolumn{9}{|l|}{ Rhinolophidae } \\
\hline $\begin{array}{l}\text { Rhinolophus guineensis } \\
\text { Einsentraut, } 1960\end{array}$ & 24 & 0.66 & 8 & 0.17 & 32 & 0.84 & 21.05 & VU \\
\hline $\begin{array}{l}\text { Rhinolophus simulator } \\
\quad \text { alticolus Sanborn, } 1960\end{array}$ & 2 & 0.05 & 0 & 0.00 & 2 & 0.05 & 1.3 & LC \\
\hline & & & & & 34 & 0.00 & 22.38 & \\
\hline \multicolumn{9}{|l|}{ Nycteridae } \\
\hline $\begin{array}{l}\text { Nycteris intermedia } \\
\text { Aellen, } 1959\end{array}$ & 0 & 0.00 & 1 & 0.03 & 1 & 0.03 & 0.66 & LC \\
\hline & & & & & 1 & & 0.66 & \\
\hline \multicolumn{9}{|l|}{ Hipposideridae } \\
\hline $\begin{array}{l}\text { Hipposideros cf.ruber } \\
\quad \text { Noack, } 1893\end{array}$ & 1 & 0.03 & 5 & 0.14 & 6 & 0.17 & 3.95 & LC \\
\hline $\begin{array}{l}\text { Hipposideros lamottei } \\
\text { Brosset, } 1984\end{array}$ & 3 & 0.08 & 0 & 0.00 & 3 & 0.08 & 1.97 & $\mathrm{CR}$ \\
\hline & & & & & 9 & & 5.92 & \\
\hline \multicolumn{9}{|l|}{ Molossidae } \\
\hline $\begin{array}{l}\text { Mops thersites (Thomas, } \\
\text { 1903) }\end{array}$ & 0 & 0.00 & 1 & 0.03 & 1 & 0.03 & 0.66 & LC \\
\hline \multirow[t]{2}{*}{$\begin{array}{l}\text { Mops brachypterus leonis } \\
\quad \text { (Thomas, 1908) }\end{array}$} & 1 & 0.03 & 0 & 0.00 & 1 & 0.03 & 0.66 & LC \\
\hline & & & & & 2 & & 1.32 & \\
\hline $\begin{array}{l}\text { TOTAL } \\
\text { MICROCHIROPTERA }\end{array}$ & & & & & 46 & 0.15 & 29.61 & \\
\hline TOTAL DATA & 83 & & 69 & & 152 & 0.27 & 100.00 & \\
\hline
\end{tabular}

captured during the dry season from adit Galery 1 (Pierre Richaud) and Gouan village II in the wet season (Table III).

Two males identified as Rhinolophus simulator alticolus Sanborn, 1936 were captured at the entrance of an adit at Pierre Richaud during the dry season (Table III).

\section{Family Nycteridae Van der Hoeven, 1855}

A single female attributed to Nycteris intermedia Aellen, 1939, was captured at Gbie during the wet season (Table III). The karyotype of the single female (GBIE 223) was $2 \mathrm{n}=34, \mathrm{NFa}=62$ and had 15 pairs of large to small metacentric and 
Table III. The range (minimum-maximum) in external standard measurements $(\mathrm{mm})$ of the bats collected during this survey: $\mathrm{N}$, sample size; FA, forearm length; TIB, tibia length; $\mathrm{E}$, ear length; $2 \mathrm{~N}$, diploid number of chromosomes; aFN, autosome fundamental number. Abbreviations for the localities: SER, Seringbara; GC, Gouan Camp; GBI, Gbie; GC, Gouan City I and II; PR, mine adit in Pierre Richaud; NA, karyotype not available.

\begin{tabular}{|c|c|c|c|c|c|c|}
\hline Species & $\mathrm{N}$ & FA: Min-Max & TIB & $\mathrm{E}$ & localities & $2 \mathrm{~N}, \mathrm{aFN}$ \\
\hline Hypsignathus monstrosus & 2 & $131-137.7$ & $56.6-59.9$ & $31-32$ & SER,GC & NA \\
\hline Epomops buettikoferi & 18 & $79.9-98.6$ & $27.6-42.9$ & $19-28$ & SER,GBI,GC & 36,68 \\
\hline Lissonycteris angolensis & 16 & $70.3-73.8$ & $28.3-33.7$ & $15-20$ & SER,PR & 36,66 \\
\hline Megaloglossus woermanni & 9 & $40.2-42.3$ & $12.2-19.3$ & $12-19$ & SER & NA \\
\hline Micropteropus pusillus & 9 & $50.4-53.4$ & $20.8-23.5$ & $13-16$ & GBI,GC & NA \\
\hline Myonycteris torquata & 9 & $42.1-62.2$ & $17.6-25.6$ & $12-16$ & SER,GC & NA \\
\hline Nanonycteris veldkampii & 29 & $40.4-53.2$ & $13.7-22$ & $12-19$ & SER & NA \\
\hline Roussettus aegyptiacus & 17 & $84.4-100$ & $31.2-46.2$ & $19-22$ & GBI,SER & 36,66 \\
\hline Rhinolophus guineensis & 41 & $44.4-47.8$ & $19.9-22.8$ & $13-19$ & PR, GCI & NA \\
\hline Rhinolophus simulator alticolus & 1 & 43.2 & $17.3-18.3$ & 19 & PR & NA \\
\hline Nycteris intermedia & 1 & 35.5 & 21.0 & 20 & GBI & 34,62 \\
\hline Hipposideros cf.ruber & 6 & $49.9-53.8$ & $19.6-22$ & $12-15$ & SER,GCI & 32,60 \\
\hline Hipposideros lamottei & 3 & $55-56.3$ & $22-25$ & $11-15$ & PR & NA \\
\hline Mops thersites & 1 & 41.0 & 15.3 & 14 & GBI & 48,70 \\
\hline Mops brachypterus leonis & 1 & 39.0 & 12.2 & 16 & SER & NA \\
\hline
\end{tabular}

\begin{tabular}{|c|c|c|c|c|c|c|c|c|}
\hline 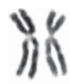 & צू & पू & $\begin{array}{l}\text { บू } \\
\text { ñ }\end{array}$ & $X X$ & หरू & ก้กั & 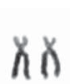 & ถ้ก \\
\hline 1 & 2 & 3 & 4 & 5 & 6 & 7 & 8 & 9 \\
\hline पूu & ע., & $r x$ & ถ้น & XY & $x x$ & $x x$ & $x x$ & \\
\hline 10 & 11 & 12 & 13 & 14 & 15 & 16 & 17 & \\
\hline
\end{tabular}

Figure 1. Standard karyotype of male Epomops buettikoferi (SER 190) $2 \mathrm{n}=35, \mathrm{NFa}=68$.

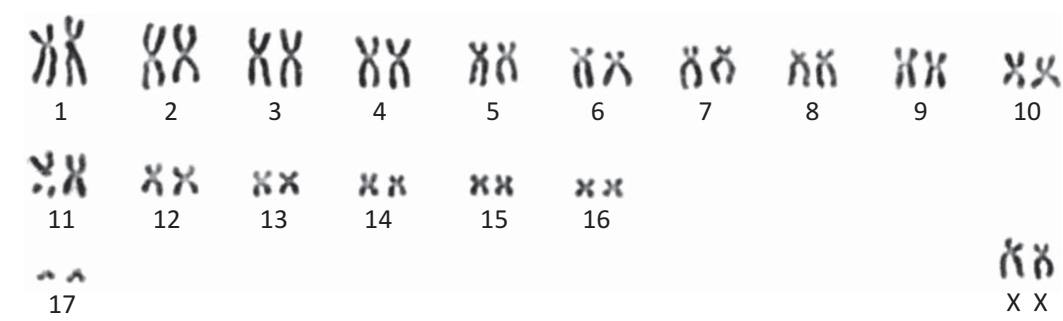

Figure 2. Standard karyotype of female of Lissonycteris angolensis smithii (SER 179) $2 \mathrm{n}=36, \mathrm{NFa}=66$.

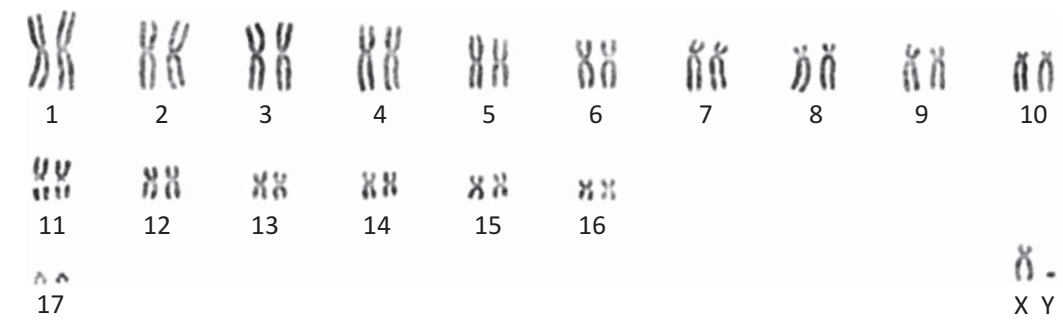

Figure 3. Standard karyotype of male Rousettus aegyptiacus unicolor (GBIE 255) $2 \mathrm{n}=36, \mathrm{NFa}=66$.

submetacentric chromosomes and one middle-sized acrocentric pair (Figure 4). The X chromosome was a submetacentric similar in size to the acrocentric autosomes.

\section{Family Hipposideridae Lyddeker, 1891}

A total of six specimens attributed to Hipposideros cf. ruber (Noack, 1893) were captured in the Nimba Mount slopes. Two of them (one male and 


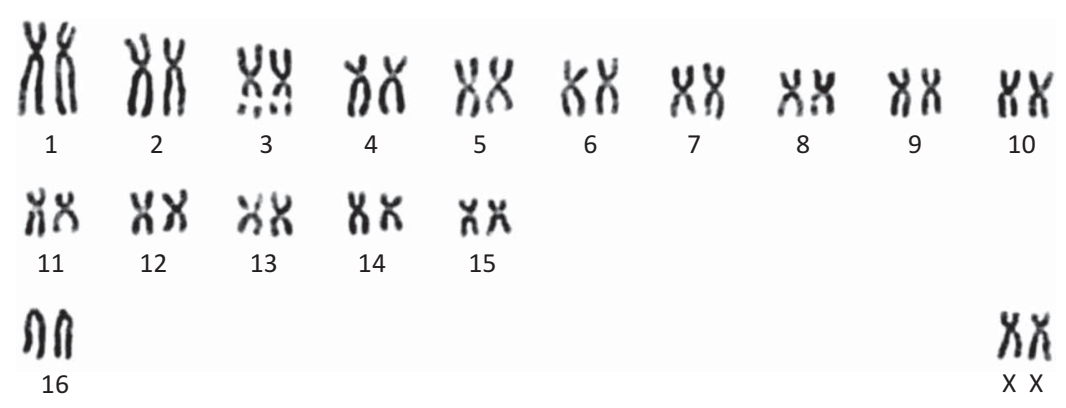

Figure 4. Standard karyotype of female Nycteris intermedia (GBIE 223) $2 \mathrm{n}=34, \mathrm{NFa}=62$.

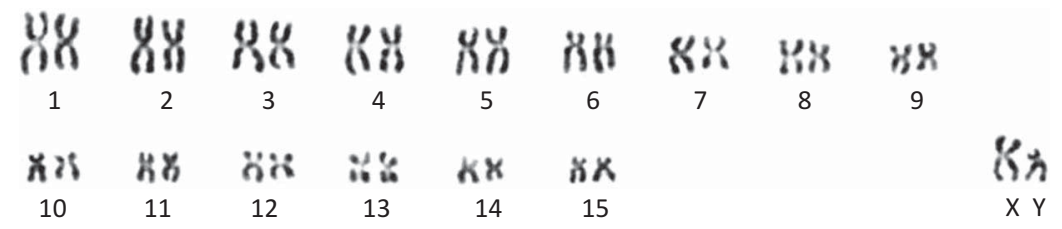

Figure 5. Standard karyotype of male Hipposideros cf ruber (SER 189) $2 \mathrm{n}=32, \mathrm{NFa}=60$.

one female) came from Gbie at the ecotone secondary forest/enclosed savanna, two (both males) from Seringbara in forest and the remaining two (both females) from Camp Cité II (Table III). One male (SER189) was karyotyped, with $2 \mathrm{n}=32$ and $\mathrm{NFa}=60$ (Figure 5). This karyotype consisted of 15 pairs of meta/submetacentric chromosomes gradually decreasing in size. The $\mathrm{X}$ chromosome was a middle-sized submetacentric and the $\mathrm{Y}$ chromosome a small subtelocentric.

Three specimens (two females and one male) of the Mount Nimba endemic Hipposideros lamottei Brosset, 1985 were all caught during the dry season at an adit at Pierre Richaud at an altitude of $1498 \mathrm{~m}$ asl (Table III). No karyotype was obtained for this species, but the Cyt. $b$ gene was sequenced and the specimens were compared directly with the type series to confirm the species taxonomic validity (Monadjem et al. submitted).

\section{Family Molossidae Gervais, 1856}

A single female attributed to Mops thersites (Thomas, 1903) was captured at Gbie during the wet season (Table III). The karyotype comprised four pairs of metacentric (of which the first pair was the largest of the set), eight pairs of subtelocentric, 11 pairs of acrocentric autosomes decreasing in size and a middle-sized submetacentric $\mathrm{X}$ chromosome, thus giving $2 \mathrm{n}=48$ and $\mathrm{NFa}=70$ (Figure 6).

Another female molossid was captured during the dry season in a nocturnal butterfly light trap in the Seringbara forest. Its morphology and external measurements (Table III) allowed us to attribute it to Mops brachypterus leonis (Peters, 1852).

\section{Discussion}

Taxonomic notes and morphological comparisons

For some species, identifications based upon external morphological grounds were not easy. By comparison, the size range of our new specimens of Rhinolophus guineensis (FA: 44.4-47.8 mm, TIB: 19.9-22.8 mm, Table III) fits well with previous records of Côte d'Ivoire and Guinea. For example, Fahr et al. (2002) trapped a single specimen from the Man region (Côte d'Ivoire) whose measurements were: FA: $45.8 \mathrm{~mm}$, TIB: $20.5 \mathrm{~mm}, E=21 \mathrm{~mm}$. At the Simandou range (Guinea), Fahr and Ebigbo (2003) reported the following measurements for $R$. guineensis: FA: $46.8-47.4(N=7)$. And finally, on the Fouta Djallon mountains (Guinea), the measurements were FA: $44.3-46.9 \mathrm{~mm}$, TIB: $19.9-22 \mathrm{~mm}$, E: 16.5-20.2 mm (Weber \& Fahr 2007).

Similarly, the skull measurements of Nycteris intermedia were GSKL (greatest skull length): $17.40 \mathrm{~mm}$; CCL (condylo-canine length) $=15.00 \mathrm{~mm}$; Zygomatic width $=10.30 \mathrm{~mm}$; MAST (mastoid width) $=7.55 \mathrm{~mm} ; \mathrm{C}-\mathrm{M} 3$ (upper teeth row length) $=6.00 \mathrm{~mm} ; \mathrm{C}-\mathrm{C}$ (inter canine width) $=4.20 \mathrm{~mm}$; M3-M3 (inter third upper molar width) $=6.45 \mathrm{~mm}$, fit within the known range for this species and confirmed the identification.

Concerning the old MNHN Lamotte collections that were examined by one of us (AM), we confirmed all previous identifications and discovered an overlooked specimen of Neoromicia cf somalica specimen (MNHN1977-559) that had been collected from "Mt. Nimba" in 1942. This specimen was not mentioned in the review of Brosset (2003). It has a GSKL of $12 \mathrm{~mm}$, the anterior premolar is absent, 


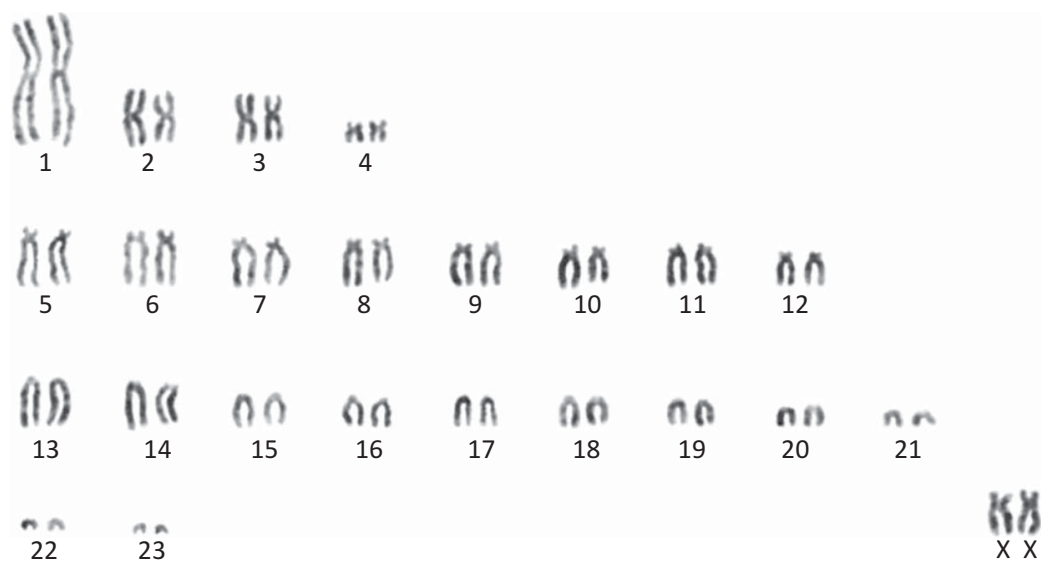

Figure 6. Standard karyotype of female Mops thersites (GBI 196) $2 \mathrm{n}=48, \mathrm{NFa}=70$.

and the outer upper incisor is half the length of the inner one and is bifid.

\section{Cytogenetic comparisons}

In this paper we provide karyotypes for the first time for two species: Epomops buettikoferi and Nycteris intermedia. We also provide for the first time karyotypes for the West African populations of Mops thersites, Lissonycteris angolensis smithii and Roussettus aegyptiacus unicolor. The standard karyotype of $E$. buettikofferi is characterized by $2 \mathrm{n}=36$ (female $\mathrm{XX}), 2 \mathrm{n}=35$ (male $\mathrm{X0}$ ) and $\mathrm{NFa}=68$, which is close to that published for E. franqueti (Peterson \& Nagorsen 1975; Haiduk et al. 1980; Primus et al. 2006), with some variation in the sex chromosome systems of males of $E$. franqueti. The karyotype of a male $E$. franqueti $(2 \mathrm{n}=36)$ from Cameroon was characterized by standard XY sex chromosome (Haiduk et al. 1980). The chromosome complement of a male $(2 \mathrm{n}=35)$ from Gabon was characterized by X0 sex chromosome. Cells in the diakinesis stage of meiosis have 18 elements, one of which appears to be an $\mathrm{X}$ chromosome univalent (Primus et al. 2006). Previously, the XX/X0 sex chromosome system was described only in E. crypturus and E. gambianus (Peterson \& Nagorsen 1975).

The karyotype of Nycteris intermedia recorded in this study $(2 \mathrm{n}=34, \mathrm{NFa}=62)$ was different from any other reported species of the genus. Peterson and Nagorsen (1975) and Rautenbach et al. (1993) both described a $2 \mathrm{n}=42, \mathrm{NFa}=78$ karyotype from specimens of $N$. thebaica collected in Zimbabwe (Rhodesia) and southern Africa. The karyotypes with $2 \mathrm{n}=42$ are also known for $N$. woodi (Rautenbach et al. 1993), $N$. hispida (T.E. Lee et al. 1989) and $N$. grandis (Porter et al. 2010).
The karyotype of Mops thersites recorded in this study $(2 \mathrm{n}=48, \mathrm{NFa}=70)$ was different in the fundamental number $(\mathrm{NFa})$ from eight other congeneric African molossid species: $M$. midas (Somalia), M. condylurus (Somalia, Senegal), M. spurrelli (Cameroon), M. brachypterus leonis (Cameroon), M. petersoni (Cameroon), M. demonstrator (Cameroon), M. nanulus (Cameroon) and $M$. thersites from Cameroon (S.A. Smith et al. 1986; Sreepada et al. 2008). All these species were characterized by a diploid number of 48 and $\mathrm{NFa}$ ranged from 54 to 66 . The autosomal complement of $M$. thersites from Cameroon includes one pair of large metacentric, three pairs of medium metacentric, three pairs of medium subtelocentric, one pair of small subtelocentric and 15 medium to small acrocentric chromosomes, which clearly differs from the $M$. thersites from Mount Nimba. In general, all species have a similar structure of karyotype. The differences may be the result of pericentric inversions and heterochromatic autosomal arm additions/deletions.

In addition, we also present the first karyotype for the west African taxon Lissonycteris angolensis smithii. Our results show that this taxon has a similar karyotype to that of $L$. angolensis angolensis (type locality is Angola) reported from Cameroon (Haiduk et al. 1980, 1981).

Rousettus aegyptiacus was initially described from Egypt but this species has populations scattered across Africa and Eurasia. The taxon present in west Africa is R. aegyptiacus unicolor (Rosevear 1965) and our documentation of its karyotype from Mount Nimba $(2 \mathrm{n}=36, \mathrm{NFa}=66)$ corresponds to $R$. aegyptiacus described from east Africa (Đulic \& Mutere 1973, 1977) and from South Africa (Haiduk et al. 1981, 1983). The karyotype of $R$. aegyptiacus from Egypt was characterised by $2 \mathrm{n}=36, \mathrm{NFa}=68$ 
(Sayed 2011). This karyotype is composed of nine pairs of metacentric, four pairs of submetacentric and four pairs of subtelocentric. The $\mathrm{X}$ chromosome was a middle-sized submetacentric and the $\mathrm{Y}$ chromosome a minute acrocentric. The autosomes of $R$. aegyptiacus described by Đulic and Mutere (1973) consist of 12 metacentric pairs, two submetacentric pairs, two subtelocentric pairs and one acrocentric pair. This difference in almost identical karyotypes results from difficulty in distinguishing between some pairs of autosomes, which may be considered as metacentric or submetacentric, as well as some other pairs of autosomes which may be considered as submetacentric or subtelocentric. Such difficulties in determining the morphology of the chromosomes are common to many other species of African bats. In our study we adhere to the terms of Đulic and Mutere (1973). The slight differences in the $\mathrm{NFa}$ number results from varying morphology of the small pair of chromosome number 17 that we, in the present work, considered as acrocentric but which was biarmed from Egyptian specimens.

Concerning Hipposideros cf ruber, our Nimba specimen has the same standard formula as documented by Koubínová et al. (2010), who reported on seven females from Senegal, $2 n=32, \mathrm{NFa}=60$. The autosomes of this species included four pairs of metacentric, eight pairs of submetacentric and three pairs of subtelocentic (considered here as submetacentric). The standard karyotype of $H$. ruber is also identical to $H$. tephrus and $H$. jonesi but it is different from the karyotype of $H$. cyclops $(2 \mathrm{n}=36, \mathrm{NFa}=62)$ and $H$. gigas $(2 \mathrm{n}=52, \mathrm{NFa}=60)$. The large variation in diploid number $(2 \mathrm{n})$ and the similar fundamental numbers of chromosomal arms $(\mathrm{NFa})$ indicate that the Robertsonian rearrangements are a probable source of karyotype variation among these species (Koubínová et al. 2010). Porter et al. (2010) noted that one specimen of $H$. caffer from Gabon had a $2 \mathrm{n}=32(\mathrm{NFa}$ not indicated) karyotype similar to most other congeneric species with $2 \mathrm{n}=32$. In our opinion, this karyotype differs in the morphology of some pairs of autosomes (see Figure 1C of Porter et al. 2010) and demands more research. We note that the $H$. ruber/caffer complex consists of several cryptic species (Vallo et al. 2008, 2011) of which at least two species occur at Mount Nimba (Monadjem et al. submitted).

\section{Mount Nimba bat community diversity and conservation}

Brosset (2003) provided a list of 39 species recorded from Mount Nimba, many of which were only known from the Liberian side of the mountain. The total number of species recorded from Guinean Nimba prior to this study was 23 (see Table IV for references). During our field work, we collected a total of 15 species from the Guinean side. The updated list for this side of the mount, provided in Table IV, is based on this new data, to which we added the taxa previously reported by Lamotte (1942), Aellen (1963), Verschuren (1976), Brosset (1985), Fahr et al. (2006) and more recently by Monadjem et al. (2013). This allows us to report the presence of a total of 29 species of bats for Guinean Mount Nimba in 12 localities (Table V). Five of these species are documented here for the first time: Hypsignathus monstrosus, Nanonycteris veldkampii, Micropteropus pusillus, Mops brachypterus leonis and Mops thersites (Table IV). Of these, H. monstrosus, $N$. veldkampii, Mops thersites and Neoromicia somalica have already been recorded from Liberian Mount Nimba (Coe 1975; Verschuren 1976; Wolton et al. 1982; Monadjem et al. 2013). The other two species (Mops brachypterus leonis and Micropteropus pusillus) are new to the whole mountain, taking the total number of bats known from the Guinean Mount Nimba up to 29 species and for the entire mountain up to 42 species. Recent surveys of bats on the Liberian side of Mount Nimba have unearthed yet more species new to the mountain (Monadjem \& Denys in prep.), underscoring the exceptional diversity of this region.

The fruit bat Nanonycteris veldkampii is known to be a migratory species in west Africa (Marshall \& MacWilliam 1982; Thomas 1983), moving to Mount Nimba at the end of the wet season (October) and possibly departing in April (Coe 1975; Wolton et al. 1982). We captured this species during both our wet and dry season sampling sessions, but we did not survey during the critical period June-September when this species is suspected to have migrated out of this region.

Most of the bat diversity at Guinean Mount Nimba is derived from lowland forest elements, as highlighted by Brosset (2003). However, the montane grasslands which are only present on the Guinean side of Mount Nimba have an interesting assemblage of cave-roosting bats that have occupied the mine adits $>1400 \mathrm{~m}$ asl. Of foremost concern is Hipposideros lamottei, which is endemic to Mount Nimba, and its entire roosting population is known from a handful of adits in the Pierre Richaud region (Monadjem et al. submitted). This area is under threat of mining for iron ore (IUCN 2012) making this species critically endangered (IUCN 2012). Despite extensive surveys on the Liberian side of the mountain, this species has not been captured beyond the borders of Guinean Mount Nimba (Monadjem 
Table IV. Bat species checklist for Guinean Nimba listing 29 species recorded from this area. The reference refers to the first publication recording the species from that locality.

\begin{tabular}{|c|c|c|c|}
\hline Family/Genus & Species & Location & Reference \\
\hline \multicolumn{4}{|c|}{ Hipposideridae } \\
\hline \multirow[t]{6}{*}{ Hipposideros } & cf ruber & Gbie & This study \\
\hline & & Grotte de Blande & Aellen (1963) \\
\hline & & Keoulenta & Aellen (1963) \\
\hline & & Seringbara & This study \\
\hline & & Ziela & Aellen (1963) \\
\hline & & Zouguepo & Aellen (1963) \\
\hline \multirow[t]{3}{*}{ Hipposideros } & lamottei & Gbie/Seringbara & This study \\
\hline & & Grotte de Blande & Brosset (1985) \\
\hline & & Pierre Richaud & Brosset (1985) \\
\hline Hipposideros & marisae & Gouan river & Aellen (1963) \\
\hline \multicolumn{4}{|l|}{ Molossidae } \\
\hline Mops & brachypterus leonis & Seringbara & This study \\
\hline Mops & spurrelli & Mt Nimba & Lamotte (1942) \\
\hline Mops & thersites & Gbie & This study \\
\hline \multicolumn{4}{|l|}{ Nycteridae } \\
\hline Nycteris & grandis & Ziela & Aellen (1963) \\
\hline \multirow[t]{2}{*}{ Nycteris } & hispida & Ziela & Aellen (1963) \\
\hline & & Zouguepo & Aellen (1963) \\
\hline \multirow[t]{2}{*}{ Nycteris } & intermedia & Ziela & Fahr et al. (2006) \\
\hline & & Gbie & This study \\
\hline Nycteris & major & Ziela & Fahr et al. (2006) \\
\hline \multicolumn{4}{|l|}{ Pteropodidae } \\
\hline Eidolon & helvum & Mt Nimba, NE & Aellen (1963) \\
\hline \multirow[t]{4}{*}{ Epomops } & buettikoferi & Gbie & Bergmans (1975) \\
\hline & & Gouan Camp & This study \\
\hline & & Mt Nimba & This study \\
\hline & & Seringbara & This study \\
\hline \multirow[t]{2}{*}{ Hypsignathus } & monstrosus & Gouan camp & This study \\
\hline & & Seringbara & This study \\
\hline \multirow[t]{3}{*}{ Lissonycteris } & angolensis smithii & Pierre Richaud & Brosset (1985) \\
\hline & & Richard Molard & Verschuren (1976) \\
\hline & & Seringbara & This study \\
\hline \multirow[t]{2}{*}{ Megaloglossus } & woermanni & Gbie & Aellen (1963) \\
\hline & & Seringbara & This study \\
\hline \multirow[t]{2}{*}{ Micropteropus } & pusillus & Ziela & This study \\
\hline & & Gouan camp & This study \\
\hline \multirow[t]{3}{*}{ Myonycteris } & torquata & Gouan camp & Verschuren (1976) \\
\hline & & Richard Molard & This study \\
\hline & & Seringbara & This study \\
\hline Nanonycteris & veldkampii & Seringbara & This study \\
\hline \multirow[t]{4}{*}{ Rousettus } & aegyptiacus unicolor & Gbie & Lamotte \& Roy (1998) \\
\hline & & Grotte de Blande & Lamotte \& Roy (1998) \\
\hline & & Grotte de $\mathrm{Zie}$ & This study \\
\hline & & Seringbara & This study \\
\hline \multicolumn{4}{|c|}{ Rhinolophidae } \\
\hline \multirow[t]{2}{*}{ Rhinolophus } & guineensis & Pierre Richaud & Brosset (1985) \\
\hline & & Seringbara & This study \\
\hline Rhinolophus & hillorum & Pierre Richaud & Fahr et al. (2006) \\
\hline Rhinolophus & simulator alticolus & Pierre Richaud & Brosset (1985) \\
\hline Vespertilionid & & & \\
\hline Kerivoula & lanosa & Ziela & Aellen (1963) \\
\hline Mimetillus & moloneyi & Ziela & Fahr et al. (2006) \\
\hline Neoromicia & cf somalica & Mt Nimba & Monadjem et al. (2013) \\
\hline Neoromicia & guineensis & Ziela & Fahr et al. (2006) \\
\hline & & Zouguepo & Aellen (1963) \\
\hline Neoromicia & nana & Ziela & Fahr et al. (2006) \\
\hline Neoromicia & tenuipinnis & Ziela & Aellen (1963) \\
\hline Scotophilus & ? & Zouguepo & Aellen (1963) \\
\hline
\end{tabular}


Table V. Gazetteer of collecting localities for bats in the Guinean Nimba.

\begin{tabular}{lccc} 
Location & Latitude & Longitude & Altitude (m) \\
\hline Gbie & 7.65 & -8.30 & $540-620$ \\
Gouan camp & 7.69 & -8.39 & $800-1200$ \\
Grotte de Blande & 7.72 & -8.35 & 520 \\
Grotte de Zie & 7.71 & -8.36 & 520 \\
Keoulenta & 7.68 & -8.31 & 450 \\
Mt Nimba & 7.68 & -8.35 & c. $500-900$ \\
Mt Nimba, NE & 7.68 & -8.35 & $500-700$ \\
Pierre Richaud & 7.66 & -8.37 & $1350-1600$ \\
Richard Molard & 7.62 & -8.42 & 1350 \\
Seringbara & 7.63 & -8.46 & $550-600$ \\
Ziela & 7.71 & -8.36 & 520 \\
Zouguepo & 7.72 & -8.39 & 510
\end{tabular}

et al. in prep.). Other bats that use the highland grasslands (at least for roosting) include the vulnerable Rhinolophus guineensis and $R$. simulator alticolus; the latter may represent a separate species (Monadjem \& Fahr 2007). Both taxa are endemic to the Upper Guinean Forest zone and are known from only a few localities (Koopman 1989; Koopman et al. 1995; Fahr et al. 2002; Fahr \& Ebigbo 2004).

\section{Conclusions}

During this survey of the Guinean side of Mount Nimba we confirmed the exceptional bat biodiversity of the area. Added to that, the presence of other endemic micro-mammals (like the otter-shrew Micropotamogale lamottei Heim de Balsac, 1954 or the Nimba shrews Crocidura nimbae Heim de Balsac, 1956, Crocidura goliath nimbasilvanus Hutterer, 2003, and the recent description of Dendromus lachaisei Denys \& Aniskine, 2012) further corroborate the importance of the Biosphere Reserve of the Nimba Mount and the need to protect all its endemics. We were able to recover living specimens of the critically endangered Hipposideros lamottei in old mine adits at high altitude, but outside the perimeter of the biosphere reserve. Since mining exploitation is due to start in the Pierre Richaud zone at the only location where Hipposideros lamottei is known to roost, the situation for the species is very serious. Excavations will lead to the reduction of the edaphic savanna above $1200 \mathrm{~m}$, which constitutes the main habitat of Hipposideros lamottei, and this will certainly affect the species whose population size is not yet known. We note here that the species was not very abundant in our survey. With this supplementary threat, this species may become extinct in an alarmingly short period of time in the absence of any further conservation management decisions.

\section{Acknowledgements}

Thanks to the NGO "Nature Conservation" and the organizers of the BIORAP (Biological Rapid Assessment) Nimba of 2008, Dr. F. Lauginie and G. Rondeau, for BHP BILLITON and the Société des Mines de Fer de Guinée (SMG). We thank Drs. L. Koivogui, B. Soropogui, F. Kourouma, M. Sylla, and C. Camara for their active participation in the field study. The research and exportation permit was provided by the Guinean Ministry "Eaux et Forêts" and we are grateful to Dr. C. Sagno and Ousmane Diallo.

\section{References}

Aellen V. 1963. La Réserve Intégrale du Mont Nimba, 29. Chiroptères. Mémoires de l'Institut Français d'Afrique Noire 66:629-638.

Bergmans W. 1975. On the differences between sympatric Epomops franqueti (Tomes, 1860) and Epomops buettikoferi (Matschie, 1899), with additional notes on the latter species (Mammalia, Megachiroptera). Beaufortia 23:141-152.

Brosset A. 1985. Chiroptères d'altitude du Mont Nimba (Guinée). Description d'une espèce nouvelle, Hipposideros lamottei. Mammalia 48 (for 1984):545-555.

Brosset A. 2003. Les chiroptères du mont Nimba. In: Lamotte M, Roy R, editors. Le peuplement animal du Mout Nimba (Guinée, Côte d'Ivoire, Liberia). Mémoires du Museum National d'Histoire Naturelle 190:687-693.

Coe MJ. 1975. Mammalian ecological studies on Mount Nimba, Liberia. Mammalia 39:523-587.

Đulic B, Mutere FA. 1973. Les chromosomes de trois espèces des Mégachiroptères (Mammalia, Chiroptera) d'Afrique orientale. Caryologia 26:389-396.

Đulic B, Mutere FA. 1977. Chromosomes of some East African bats. Säugetierkundliche Mitteilungen 25:231-233.

Fahr J, Djossa BA, Vierhaus H. 2006. Rapid assessment of bats (Chiroptera) in Déré, Diécké and Mt. Béro classified forests, southeastern Guinea; including a review of the distribution of bats in Guinée Forestière. In: Wright, HE, McCullough J, Alonso LE, Diallo MS, editors. A rapid biological assesssment of three classified forests in Southeastern Guinea. Washington, DC: Conservation International. pp. 168-180.

Fahr J, Ebigbo NM. 2003. A conservation assessment of the bats of the Simandou Range, Guinea, with the first record of Myotis welwitschii (Gray, 1866) from West Africa. Acta Chiropterologica 5:125-141.

Fahr J, Ebigbo NM. 2004. Chapter 6. Rapid survey of bats (Chiroptera) in the Forêt Classée du Pic de Fon, Guinea. In: McCullough J, editor. A rapid biological assessment of the Forêt Classée du Pic de Fon, Simandou Range, southeastern Republic of Guinea. RAP Bulletin of Biological Assessment. Washington, DC: Center for Applied Biodiversity Science (CABS), Conservation International, Rio Tinto. pp. 69-77.

Fahr J, Ebigbo NM, Formenty P. 2002. The bats (Chiroptera) of Mt. Sangbé National Park. Unpublished Report, 33 pp.

Fahr J, Kalko EKV. 2011. Biome transitions as centres of diversity: Habitat heterogeneity and diversity patterns of West African bat assemblages across spatial scales. Ecography 34:177-195.

Haiduk MW, Baker RJ, Robbins KW, Schlitter DA. 1981. Chromosomal evolution in African megachiroptera: G- and C-band assessment of the magnitude of change in similar standard karyotypes. Cytogenetics and Cell Genetics 29:221-232. 
Haiduk MW, Robbins LW, Robbins RL, Schlitter DA. 1980. Karyotypic studies of seven species of African Megachiropterans (Mammalia: Pteropodidae). Annals of the Carnegie Museum 49:181-191.

Haiduk MW, Robbins LW, Schlitter DA. 1983. Chromosomal banding studies and their systematic implications in African fruit bats (Chiroptera: Pteropodidae). Annales Musée Royal de l'Afrique Centrale, Sciences Zoologiques 237:1-8.

Hill JE. 1982. Records of bats from Mount Nimba, Liberia. Mammalia 46:116-120.

IUCN (International Union for Conservation of Nature). 2012. IUCN red list of threatened species. Version 2012.1. Available: www.iucnredlist.org Accessed Jul 201201.

Kasso M, Bekele A, Hemson G. 2010. Species composition, abundance and habitat association of rodents and insectivores from Chilalo-Galama Mountain range, Arsi, Ethiopia. African Journal of Ecology 48:1105-1114.

Kingdon J. 1990. Island Africa: The evolution of Africa's rare animals and plants. Princeton: Princeton University Press.

Kingston T, Lara MC, Jones G, Zubaid A, Kunz TH. 2001. Acoustic divergence in two cryptic Hipposideros species: A role for social selection? Proceedings of the Royal Society B 268:1381-1386.

Koopman KF. 1989. Systematic notes on Liberian bats. American Museum Novitates 2946:1-11.

Koopman KF, Kofron CP, Chapman A. 1995. The bats of Liberia: Systematics, ecology, and distribution. American Museum Novitates 3148:1-24.

Koubínová D, Sreepada KS, Koubek P, Zima J. 2010. Karyotypic variation in rhinolophid and hipposiderid bats (Chiroptera: Rhinolophidae, Hipposideridae). Acta Chiropterologica 12:393-400.

Lamotte M. 1942. La faune mammalogique du Mont Nimba (Haute-Guinée). Mammalia 6:114-119.

Lamotte M, Roy R. 1962. Les traits principaux du peuplement animal de la prairie montagnarde du mont Nimba (Guinée). Recherches Africaines. Etudes guinéennes (nouvelle série) $1: 11-30$.

Lamotte M, Roy R. 1998. 5. La faune et le peuplement animal du Nimba. In: Lamotte $M$, editor. Le Mont Nimba, réserve de biosphère et site du patrimoine mondial (Guinée et Côte d'Ivoire). Initiation à la géomorphologie et à la biogéographie. Paris: UNESCO. pp. 81-132.

Lee MR, Elder FFB. 1980. Yeast stimulation of bone marrow mitosis for cytogenetic investigations. Cytogenetics and Cell Genetics 26:36-40.

Lee TE Jr, Bickham JW, Schlitter DA. 1989. Karyotypes of two Nycterid bats from Somalia. Mammalia 53:120-121.

Marshall AG, McWilliam AN. 1982. Ecological observations on epomorphine fruit bats (Megachiroptera) in West African savanna woodlands. Journal of Zoology, London 198: 53-67.

Missoup AD, Nicolas V, Wendelen W, Keming E, Bilong Bilong CF, Couloux A, Atanga E, Hutterer R, Denys C. 2012 Systematics and diversification of Praomys species (Rodentia: Muridae) endemic to the Cameroon Volcanic Line (West central Africa). Zoologica Scripta 41:327-345.

Mittermeier RA, Robles Gil P, Hoffman M, Pilgrim J, Brooks T, Goettsch Mittermeier C, Lamoreux J, da Fonseca GAB. 2005. Hotspots revisited: Earth's biologically richest and most endangered terrestrial ecoregions. Danville, CA, USA Booksleuth.

Monadjem A, Fahr J. 2007. Rapid survey of Bats of North Lorma, Gola and Grebo national forests, with notes on shrews and rodents. Arlington, VA: Conservation International.
Monadjem A, Richards L, Taylor PJ, Stoffberg S. 2013. High diversity of pipistrelloid bats (Vespertilionidae: Hypsugo, Neoromicia, and Pipistrellus) in a West African rainforest with the description of a new species. Zoological Journal of the Linnean Society 167:191-207.

Myers N, Mittermeier RA, Mittermeier CG, da Fonseca GAB, Kent J. 2000. Biodiversity hotspots for conservation priorities. Nature 403:853-858.

Newmark WD. 2002. Conserving biodiversity in East African forests. A study of the Eastern Arc Mountains. Ecological Studies 155. Berlin: Springer-Verlag.

Nicolas V, Missoup AD, Denys C, Kerbis Petehans J, Katuala P, Couloux A, Colyn M. 2011. The roles of rivers and Pleistocene refugia in shaping genetic diversity in Praomys misonnei in tropical Africa. Journal of Biogeography 38:191-207.

Olson DM, Dinerstein E, Wikramanayake ED, Burgess ND, Powell GVN, Underwood EC, D'amico JA, Itoua I, Strand HE, Morrison JC, Loucks CJ, Allnutt TF, Ricketts TH, Kura Y, Lamoreux JF, Wettengel WW, Hedao P, Kassem KR. 2001. Terrestrial ecoregions of the world: A new map of life on Earth. A new global map of terrestrial ecoregions provides an innovative tool for conserving biodiversity. BioScience 51:933-938.

Peterson RL, Nagorsen DW. 1975. Chromosomes of fifteen species of bats (Chiroptera) from Kenya and Rhodesia. Life Science Occasional Papers - Royal Ontario Museum 27: $1-14$

Porter CA, Primus AW, Hoffmann FG, Baker RJ. 2010. Karyology of five species of bats (Vespertilionidae, Hipposideridae, and Nycteridae) from Gabon with comments on the taxonomy of Glauconycteris. Occasional Papers of the Museum, Texas Tech University 295:1-7.

Primus AW, Harvey J, Guimondou S, Mboumba JF, Ngangui R, Hoffmann FG, Baker RJ, Porter CA. 2006. Karyology and chromosomal evolution of some small mammals inhabiting the rainforest of the Rabi oil field, Gabon. In: Gamba, Gabon: Biodiversity of an equatorial African rainforest. Alonso A, Lee ME, Campbell P, Pauwels OSG, Dallmeier F, editors. Bulletin of the Biological Society of Washington 12:371-382

Rautenbach IL, Bronner GN, Schlitter DA. 1993. Karyotypic data and attendant systematic implications for the bats of southern Africa. Koedoe 36:87-104

Rosevear DR. 1965. The bats of West Africa. London: Trustees of the British Museum (Natural History).

Sayed NHM. 2011. Phylogenetic relationship between the Fruit Bat (Rousettus aegyptiacus) and Lesser Tailed Bat (Rhinopoma Hardwickei) inferred from G-Banded chromosomes and electrophoretic protein pattern analysis. Journal of American Science 7:656-669.

Smith SA, Bickham JW, Schlitter DA. 1986. Karyotypes of eleven species of Molossid bats from Africa (Mammalia: Chiroptera). Annals of the Carnegie Museum 55:125-136.

Smith TB, Calsbeek R, Wayne RK, Holder KH, Pires D, Bardeleben C. 2005. Testing alternative mechanisms of evolutionary divergence in an African rain forest passerine bird. Journal of Evolutionary Biology 18:257-268.

Sreepada KS, Koubínová D, Konečný A, Koubek P, Ráb P, Rábová M, Zima J. 2008. Karyotypes of three species of molossid bats (Molossidae, Chiroptera) from India and western Africa. Folia Zoologica 57:347-357

Stanley WT, Goodman SM. 2011. Small mammals inventories in the East and West Usambara Mountains, Tanzania. 4. Rodentia. Fieldiana Life and Earth Sciences 4:53-73.

Taylor PJ, Stoffberg S, Monadjem A, Schoeman M, Bayliss J, Cotterill FPD. 2012. Four new bat species (Rhinolophus 
hildebrandtii complex) reflect Plio-Pleistocene Divergence of dwarfs and giants across an Afromontane Archipelago. Plos One 7: e7744.

Thomas DW. 1983. The annual migrations of three species of West African fruit bats (Chiroptera: Pteropodidae). Canadian Journal of Zoology 61:2266-2272.

Vallo $\mathrm{P}$, Benda $\mathrm{P}$, Martínková $\mathrm{N}$, Kaňuch $\mathrm{P}$, Kalko EKV, Červený J, Koubek P. 2011. Morphologically uniform bats Hipposideros aff. ruber (Hipposideridae) exhibit high mitochondrial genetic diversity in southeastern Senegal. Acta Chiropterologica 13:79-88.

Vallo P, Guillén-Servent A, Benda P, Pires DB, Koubek P. 2008. Variation of mitochondrial DNA in the Hipposideros caffer complex (Chiroptera: Hipposideridae) and its taxonomic implications. Acta Chiropterologica 10: 193-206.

Verschuren J. 1976. Les Cheiroptères du mont Nimba (Liberia). Mammalia 40:615-632.
Yalden DW, Largen MJ. 1992. The endemic mammals of Ethiopia. Mammal Review 22:115-150.

Weber N, Fahr, J. 2007. Survey of endemic and globally threatened bat species in the Fouta Djallon Highlands for conservation priorities in Guinea. Final project report to the Van Tienhoven Foundation for international nature protection, Conservation International \& Guinée Ecologie. Ulm, Germany: Ulm University.

White F. 1981. The history of the Afromontane archipelago and the scientific need for its conservation. African Journal of Ecology 19:33-54.

Wilson DE, Reeder DM. 2005. Mammals species of the world. A taxonomic and geographic reference. Baltimore, MD: The John Hopkins University Press.

Wolton RJ, Arak PA, Godfray HJ, Wilson RP. 1982. Ecological and behavioural studies of the Megachiroptera at Mount Nimba, Liberia, with notes on Microchiroptera. Mammalia 46:419-448. 